\title{
Deaths in Children with Prader-Willi Syndrome
}

\author{
A Contribution to the Debate about the Safety of Growth Hormone Treatment in \\ Children with PWS
}

\section{Urs Eiholzer}

Foundation Growth Puberty Adolescence, Zurich, Switzerland

\section{Key Words}

Prader-Willi syndrome, mortality - Obstructive respiratory disorder - Hypoventilation - Sleep apnea • Sudden death

\begin{abstract}
Irrespective of GH treatment, children with Prader-Willi syndrome (PWS) suffer more frequently and more seriously from respiratory problems than healthy children. The pathogenesis of such respiratory problems in PWS seems to be multifactorial in origin, but mainly related to insufficiency of respiratory muscles and pharyngeal narrowness. Deaths of children with PWS are reported among GH treated as well as untreated children. Our data show that also disturbed body composition plays an important role in fatal outcomes, possibly enhancing the ventilation disorder. For several years, in our recommendations we have pointed out the secondary risks of increasing obesity. In addition, it is recommended for all children with PWS, in particular before institution of GH therapy, to have polysomnography and an otorhinolaryngologic examination performed, and tonsillectomy in the case of enlarged tonsils. Furthermore, upper airway infections should be treated aggressively.
\end{abstract}

\section{KARGER}

Fax +4161306 1234 E-Mail karger@karger.ch www.karger.com www.karger.com/hre
Patients with Prader-Willi syndrome (PWS), in addition to disturbed body composition, suffer from numerous medical problems, particularly in relation to respiration. Following two case reports from our group concerning the death of 2 children during growth hormone treatment (GHT) [1,2] and the subsequently reported sudden death of further children [3, 4], a controversy arose concerning the safety of GHT in children with PWS. In this paper we would like to present currently known facts about the deceased children and develop some hypotheses about mortality in children with PWS.

\section{Data on Deceased Children with PWS without GHT}

In very recent publications $[5,6]$ case reports of children with PWS not treated with GH, who died, were collected through two European and American international searches, based on collaboration with many healthcare professionals and through announcements in journals/meetings/ groups of professionals. Moreover, two case reports [7, 8] were published and one further case was reported from Austria [9] (table 1). Of the total of 23 cases below age 18, one child died in an accident; 17 of the remaining 22 died from infections, and 5 of 22 from sleep apnea or hypoventilation and aspiration. Deaths resulting from infections were mostly related to the respiratory tract $(n=11)$ or to

Dr. Urs Eiholzer

Foundation Growth Puberty Adolescence

Moehrlistrasse 69

$\mathrm{CH}-8006$ Zurich (Switzerland)

Tel. +41 4436437 00, Fax +41 4436437 01, E-Mail mail@childgrowth.org 
Table 1. Patients $<18$ years with PWS who died spontaneously

\begin{tabular}{|c|c|c|c|c|c|c|c|c|c|c|c|}
\hline $\begin{array}{l}\text { Patient } \\
\text { No. }\end{array}$ & Country & $\begin{array}{l}\text { Death } \\
\text { date }\end{array}$ & $\begin{array}{l}\text { Age }_{\text {death }} \\
\text { years }\end{array}$ & Sex & GH & $\begin{array}{l}\text { Relat. } \\
\text { weight, } \%\end{array}$ & $\begin{array}{l}\mathrm{BMI} \\
\mathrm{kg} / \mathrm{m}^{2}\end{array}$ & $\begin{array}{l}\text { BMI } \\
\text { SDS }\end{array}$ & Cause of death & Autopsy findings & Medical history \\
\hline 1 & Japan [13] & 1991 & 0.5 & $\mathrm{f}$ & none & & & & pneumonia, cardiac decomp. & & \\
\hline 2 & Estonia [8] & 2002 & 3.5 & $\mathrm{f}$ & none & $>200$ & & & bronchitis, cardiac arrest & & narcolepsy \\
\hline 3 & NL [5] & & 0 & $\mathrm{~m}$ & none & not obese & & & prematurity, sepsis & E. coli sepsis & \\
\hline 4 & France [5] & & 0.25 & $\mathrm{~m}$ & none & not obese & & & hypoventilation & aspiration & \\
\hline 5 & Belgium [5] & & 0.66 & $\mathrm{f}$ & none & not obese & & & pneumonia & n.d. & \\
\hline 6 & NL [5] & & 0.83 & $\mathrm{~m}$ & none & not obese & & & hypoventilation, aspiration & n.d. & \\
\hline 7 & USA [5] & & 1.33 & $\mathrm{~m}$ & none & not obese & & & sleep apnea, SIDS & SIDS & recurrent pneumonia \\
\hline 8 & USA [5] & & 2 & $\mathrm{~m}$ & none & not obese & & & sudden resp.fail., pneumonia & pneumonia & \\
\hline 9 & NL [5] & & 2 & $\mathrm{~m}$ & none & not obese & & & pneumonia, Strep. A & bronchopneumonia & \\
\hline 10 & NL [5] & & 2 & $\mathrm{f}$ & none & not obese & & & shock, DIC, gastroenteritis & n.d. & enteritis \\
\hline 11 & USA [5] & & 3 & $\mathrm{f}$ & none & not obese & & & accident & n.d. & \\
\hline 12 & NL [5] & & 3 & $\mathrm{~m}$ & none & not obese & & & SIDS, gastroenteritis & enteritis & enteritis \\
\hline 13 & Belgium [5] & & 3 & $\mathrm{f}$ & none & not obese & & & SIDS, early morning unexp. & SIDS & $\begin{array}{l}\text { respiratory } \\
\text { tract infection }\end{array}$ \\
\hline 14 & USA [5] & & 3 & $\mathrm{~m}$ & none & not obese & & & abscess, Strep. A & $\begin{array}{l}\text { parapharyngeal } \\
\text { abscess }\end{array}$ & \\
\hline 15 & NL [5] & & 5 & $\mathrm{f}$ & none & $>120$ & & & SIDS, resp. tract infection & bronchopneumonia & \\
\hline 16 & Belgium [5] & & 9 & $\mathrm{~m}$ & none & $>200$ & & & pneumonia, cardiac decomp. & n.d. & \\
\hline 17 & USA [6] & & 0.42 & $\mathrm{~m}$ & none & 72 & 11.8 & -3.65 & fever, mild pneumonia, SIDS & alveolar infiltrate & failure to thrive \\
\hline 18 & USA [6] & & 0.75 & $\mathrm{~m}$ & none & 88 & 15.5 & -1.08 & fever, gastroenteritis & $\begin{array}{l}\text { enteritis, mild } \\
\text { meningitis }\end{array}$ & \\
\hline 19 & Canada [6] & & 1.58 & $\mathrm{f}$ & none & & & & fever, resp. tract infection & n.d. & failure to thrive \\
\hline 20 & UK [6] & & 1.67 & $\mathrm{f}$ & none & 70 & 12.2 & -3.61 & $\begin{array}{l}\text { fever, diarrhea, DIC, } \\
\text { unexpected death }\end{array}$ & $\begin{array}{l}\text { alveolar hemorrhage, } \\
\text { bronchiolitis }\end{array}$ & \\
\hline 21 & USA [6] & & 3.5 & $\mathrm{~m}$ & none & 154 & & & SIDS, apnea & n.d. & failure to thrive \\
\hline 22 & USA [6] & & 3.5 & $\mathrm{f}$ & none & 137 & 21.7 & 5.26 & $\begin{array}{l}\text { diarrhea (rotavirus), } \\
\text { aspiration }\end{array}$ & $\begin{array}{l}\text { aspiration; cerebral } \\
\text { malformation }\end{array}$ & \\
\hline 23 & Austria [9] & 2002 & 3.1 & $\mathrm{~m}$ & none & 139 & 22.8 & 3.7 & $\begin{array}{l}\text { sudden death, respiratory } \\
\text { infection }\end{array}$ & n.d. & $\begin{array}{l}\text { premature } 31 \text { weeks } \\
\text { laryngotracheo } \\
\text { bronchitis }\end{array}$ \\
\hline Cases & & & 23 & $13 m$ & & 21 & 5 & 5 & & & \\
\hline Median & & & 2 & $10 f$ & & 6 obese & 15.5 & -1.08 & & & \\
\hline Min & & & 0 & & & & 11.8 & -3.65 & & & \\
\hline $\operatorname{Max}$ & & & 9 & & & & 22.8 & 5.26 & & & \\
\hline
\end{tabular}

n.d. $=$ Not done; SIDS = sudden infant death syndrome; DIC = disseminated intravascular coagulopathy

gastrointestinal disease $(n=5)$. The clinical course of the respiratory infections in the children was shorter and more acute than anticipated, and death occurred rather suddenly and unexpectedly. Out of 21 children, weight status was known in 19, and only 6 of them were reported to be obese $[5,7-9]$; in 15 children, however, no accurate data on weight and height had been provided.

The mortality rate in patients with PWS not treated with $\mathrm{GH}$ was recently estimated at $3 \%$ per year between age 6 and 56 years compared to $0.13 \%$ in the general population below 55 years [10]. Even though mortality rate in children aged $0-5$ years was not estimated, more recent reports on causes of death in PWS have predominantly included children younger than 5 years. Therefore, the reported spontaneous death in 22 children up to 5 years of age is most likely far below the actual mortality in this age group. In addition, because PWS has only been diagnosed in early childhood very recently [11], a substantial number of young children with PWS may have died without having been diagnosed with PWS. Unfortunately, there is no national or international registry recording all patients with PWS who died, whether treated with $\mathrm{GH}$ or not.

\section{Data on Deceased Children with PWS Treated with GH and Comparison with Living Controls}

Prompted by our case reports on 2 patients who died during GHT [1, 2], Pharmacia/Pfizer searched the KIGS database for similar cases [3]; of a total of 675 children on GHT with documented PWS, three had died $(0.44 \%$ until fall 2003) [12]. Further cases were found through the Pharmacovigilance databases [12] and case reports as 
Table 2. Patients $<18$ years with PWS who died during GHT

\begin{tabular}{|c|c|c|c|c|c|c|c|c|c|c|c|c|}
\hline \multirow{2}{*}{$\begin{array}{l}\text { Patient } \\
\text { No. }\end{array}$} & \multirow{2}{*}{ Country } & \multirow{2}{*}{$\begin{array}{l}\text { Year } \\
\text { of } \\
\text { death }\end{array}$} & \multirow{2}{*}{\multicolumn{2}{|c|}{$\begin{array}{l}\text { Age }_{\text {death }} \mathrm{Sex} \\
\text { years }\end{array}$}} & \multicolumn{2}{|c|}{$\mathrm{GH}$ treatment } & \multirow{2}{*}{$\begin{array}{l}\text { Relat. } \\
\text { weight } \\
\%\end{array}$} & \multirow{2}{*}{$\begin{array}{l}\mathrm{BMI} \\
\text { (Prader) } \\
\mathrm{kg} / \mathrm{m}^{2}\end{array}$} & \multirow{2}{*}{$\begin{array}{l}\text { BMI } \\
\text { (Prader) } \\
\text { SDS }\end{array}$} & \multirow{2}{*}{ Cause of death } & \multirow[t]{2}{*}{ Autopsy findings } & \multirow[t]{2}{*}{ Medical history } \\
\hline & & & & & $\begin{array}{l}\text { dose } \\
\mathrm{mg} / \mathrm{kg} \cdot \mathrm{w}\end{array}$ & $\begin{array}{l}\text { duration } \\
\text { months }\end{array}$ & & & & & & \\
\hline 1 & $\begin{array}{l}\text { Switzerland } \\
{[2]}\end{array}$ & 1999 & 0.7 & $\mathrm{~m}$ & 0.18 & 2.5 & 119 & 20.2 & 2.7 & $\begin{array}{l}\text { sudden death } \\
\text { during } \\
\text { bottle feeding; }\end{array}$ & bronchopneumonia & $\begin{array}{l}\text { fever; } \\
\text { hypoventilation, } \\
\text { sleep apnea } \\
\text { signs of pulmonary } \\
\text { hypertension }\end{array}$ \\
\hline 2 & $\begin{array}{l}\text { Switzerland } \\
{[1]}\end{array}$ & 2000 & 6.5 & $\mathrm{~m}$ & 0.26 & 5.0 & 156 & 23.8 & 6.6 & $\begin{array}{l}\text { hypoventilation, } \\
\text { sleep apnoea }\end{array}$ & no autopsy & nocturnal apnea \\
\hline 3 & $\begin{array}{l}\text { Japan [3] } \\
\text { KIGS }\end{array}$ & & 15.8 & $\mathrm{~m}$ & 0.1 & 7.0 & 230 & 38.0 & 7.11 & $\begin{array}{l}\text { acute pneumonia, } \\
\text { sudden resp.failure }\end{array}$ & no autopsy & \\
\hline 4 & $\begin{array}{l}\text { Spain [3] } \\
\text { KIGS }\end{array}$ & 2001 & 8.0 & $\mathrm{~m}$ & 0.15 & 0.5 & 206 & 31.6 & 10.7 & $\begin{array}{l}\text { resp. insufficiency, } \\
\text { acute bronchitis }\end{array}$ & $\begin{array}{l}\text { respiratory } \\
\text { insufficiency }\end{array}$ & $\begin{array}{l}\text { moderate OSA, } \\
\text { severe nocturnal } \\
\text { hypoventilation }\end{array}$ \\
\hline 5 & $\begin{array}{l}\text { USA [3] } \\
\text { KIGS }\end{array}$ & 2001 & 4.7 & $\mathrm{~m}$ & 0.24 & 3.0 & 212 & 31.3 & 14.0 & $\begin{array}{l}\text { aspiration } \\
\text { pneumonia } \\
\text { respiratory failure }\end{array}$ & no autopsy & $\begin{array}{l}\text { sleep apnea; non } \\
\text { compliant with GH }\end{array}$ \\
\hline 6 & USA [3] & & 3.0 & $\mathrm{~m}$ & 0.12 & 3.0 & 210 & & & found dead in bed & pneumonitis & asthma (Salbuterol) \\
\hline 7 & Canada [4] & 2002 & 4.0 & $\mathrm{~m}$ & 0.16 & 2.0 & 262 & 40.5 & 20.4 & pneumonia & $\begin{array}{l}\text { bronchopneumonia } \\
\text { subdural hematoma }\end{array}$ & $\begin{array}{l}\text { snoring, benign } \\
\text { intracranial } \\
\text { hypertension }\end{array}$ \\
\hline 8 & USA [12] & 2003 & 3 & $\mathrm{f}$ & $0.5 \mathrm{mg} / \mathrm{c}$ & $\mathrm{d} 30$ & somewh & hat obese & & pneumonia & $\begin{array}{l}\text { physician waiting } \\
\text { for final report }\end{array}$ & $\begin{array}{l}\text { several apiration } \\
\text { pneumonias, non- } \\
\text { compliant with GH }\end{array}$ \\
\hline 9 & UK [12] & & 13.0 & $\mathrm{~m}$ & & 5.0 & & & & $\begin{array}{l}\text { sudden death, } \\
\text { unexplained }\end{array}$ & & \\
\hline 10 & UK [12] & 2003 & 14.6 & $\mathrm{~m}$ & 0.11 & 18 & 254 & 42.0 & 8.34 & $\begin{array}{l}\text { viral URI, resp. } \\
\text { failure, severe } \\
\text { right heart failure }\end{array}$ & & $\begin{array}{l}\text { OSA, chronic heart } \\
\text { failure, type } 2 \\
\text { diabetes }\end{array}$ \\
\hline 11 & Japan [12] & & 14 & $\mathrm{f}$ & & 48 & & & & $\begin{array}{l}\text { drowned in the } \\
\text { bathtub }\end{array}$ & & \\
\hline 12 & Austria [13] & 1999 & 4.9 & $\mathrm{f}$ & 0.24 & 2.0 & 127 & 19.5 & 3.95 & $\begin{array}{l}\text { sudden death, } \\
\text { cardiorespiratory } \\
\text { failure }\end{array}$ & no autopsy & $\begin{array}{l}\text { sleep apnea, CPAP; } \\
\text { pulmonalis } \\
\text { pressure increase } \\
\text { during GH }\end{array}$ \\
\hline 13 & Italy [14] & 2003 & 3.9 & $\mathrm{~m}$ & 0.15 & 7.0 & 226 & 28 & 10.9 & $\begin{array}{l}\text { sudden death, } \\
\text { unexplained }\end{array}$ & no autopsy & $\begin{array}{l}\text { maternal gestational } \\
\text { diabetes; slightly } \\
\text { abnormal cranial CT }\end{array}$ \\
\hline Cases & & & 13 & & 11 & 13 & 10 & 9 & 9 & & & \\
\hline Median & & & 4.9 & & 0.16 & 5.0 & 211 & 31.3 & 8.34 & & & \\
\hline Min & & & 0.7 & & 0.10 & 0.5 & 119 & 19.5 & 2.7 & & & \\
\hline Max & & & 15.8 & & 0.26 & 48.0 & 262 & 42 & 20.4 & & & \\
\hline
\end{tabular}

$\mathrm{w}=$ Week; OSA = obstructive sleep apnea.

well as through personal communication [13]. No new cases were reported to KIGS until today [12] (table 2).

Despite major effort including the above-mentioned databases and personal contacts with involved persons and centers caring for patients with PWS, it was not possible to obtain more information than provided in this paper.

\section{Respiration}

As shown in table 2, 10 of 13 children died in the context of respiratory insufficiency; respiratory problems were documented in 9 of these 10 children before they started GHT. 
Table 3. Controls matched to deceased children with PWS documented in table 2 for 1. duration of GHT, 2. age, 3. sex

\begin{tabular}{|c|c|c|c|c|c|c|c|c|}
\hline \multicolumn{2}{|l|}{ Patients } & \multirow{2}{*}{$\begin{array}{l}\mathrm{Age}_{\text {death }} \\
\text { years }\end{array}$} & \multirow[t]{2}{*}{ Sex } & \multicolumn{2}{|c|}{$\mathrm{GH}$ treatment } & \multirow{2}{*}{$\begin{array}{l}\text { Rel. } \\
\text { weight } \\
\%\end{array}$} & \multirow{2}{*}{$\begin{array}{l}\text { BMI } \\
\text { (Prader) } \\
\mathrm{kg} / \mathrm{m}^{2}\end{array}$} & \multirow{2}{*}{$\begin{array}{l}\text { BMI } \\
\text { (Prader } \\
\text { SDS }\end{array}$} \\
\hline $\begin{array}{l}\text { No. } \\
\text { tab.2 }\end{array}$ & initial & & & $\begin{array}{l}\text { dose } \\
\mathrm{mg} / \mathrm{kg} \cdot \text { week }\end{array}$ & $\begin{array}{l}\text { duration } \\
\text { months }\end{array}$ & & & \\
\hline ad 1 & $\mathrm{MZ}$ & 0.65 & $\mathrm{~m}$ & 0.29 & 3 & 98 & 16.1 & -0.45 \\
\hline ad 2 & PS & 7 & $\mathrm{f}$ & 0.29 & 6 & 121 & 18.7 & 2.99 \\
\hline ad 3 & \multicolumn{8}{|c|}{ no patient found to match the pubertal patient during 7 months of GHT } \\
\hline ad 4 & $\mathrm{AM}$ & 7.6 & $\mathrm{f}$ & 0.33 & 6 & 99 & 15.1 & -0.27 \\
\hline ad 5 & HR & 4.7 & $\mathrm{f}$ & 0.30 & 3 & 115 & 17.5 & 1.64 \\
\hline ad 6 & GD & 3.5 & $\mathrm{~m}$ & 0.23 & 3 & 116 & 17.5 & 1.81 \\
\hline ad 7 & ES & 4.3 & $\mathrm{~m}$ & 0.33 & 3 & 93 & 14.0 & -1.04 \\
\hline ad 8 & $\mathrm{MG}$ & 2.95 & $\mathrm{~m}$ & 0.30 & 31.5 & 110 & 17 & 1.24 \\
\hline ad 9 & MS & 13.2 & $\mathrm{f}$ & 0.40 & 6 & 109 & 17.3 & -0.19 \\
\hline ad 10 & $\mathrm{SM}$ & 14.8 & $\mathrm{f}$ & 0.25 & 17 & 123 & 20.3 & 0.52 \\
\hline ad 11 & MA & 14.05 & $\mathrm{f}$ & 0.20 & 60 & 126 & 23.7 & 2.88 \\
\hline ad 12 & $\mathrm{CD}$ & 5.3 & $\mathrm{f}$ & 0.26 & 2 & 124 & 18.9 & 3.27 \\
\hline ad 13 & PB & 3.6 & $\mathrm{~m}$ & 0.38 & 7 & 90 & 14.1 & -0.93 \\
\hline Cases & & 11 & & 11 & 11 & 11 & 11 & 11 \\
\hline Median & & 5.30 & & 0.29 & 6.00 & 115 & 17.50 & 1.24 \\
\hline Min & & 0.65 & & 0.20 & 2.00 & 93 & 14.00 & -1.04 \\
\hline Max & & 14.80 & & 0.40 & 60.00 & 126 & 23.70 & 3.27 \\
\hline
\end{tabular}

\section{Duration of GHT}

It was seen that GHT duration in 10 of the deceased children amounted to a maximum of 7 months; most children died during the first 3 months of therapy. The 3 remaining children who had been treated with GH for a longer time had suffered from particular additional problems: \#8 was noncompliant with GHT, \#10 had morbid obesity with obstructive sleep apnea and heart failure and \#11 drowned in the bathtub.

\section{Weight Indices}

In 9 with sufficient data on weight of 13 deceased patients, BMI and BMI SDS could be calculated, 11 were described to be 'obese'. For comparison purposes, we matched every deceased child with a child of our current study using the following criteria: (1) duration of therapy; (2) age, and (3) sex (table 3). If more than one candidate was found, the mean of the suitable children was used. It was found that the deceased children were markedly more obese than the controls from our study, and the $\mathrm{GH}$ dose was similar or even lower in the deceased children.

In a second attempt to compare the weight of the deceased children with controls we compared the weight indices of the two deceased children from our own study with all other children of the same age groups of our study (table 4). The first child died at the age of 7 months, 2.5
Table 4. Comparison between the weight indices of the 2 deceased children from our own study with all other children of the same age groups of our study

\begin{tabular}{lcc}
\hline After 3 months GHT & Patient 1 & $\begin{array}{l}\text { Control group 1, } \mathrm{n}=10 \\
\text { median (range) }\end{array}$ \\
\hline Age, years & 0.7 & $0.9(0.6-1.4)$ \\
Relative weight, \% & 119 & $88.2(70.6-100.0)$ \\
BMI, kg/m ${ }^{2}$ & 20.2 & $14.9(12.1-17.0)$ \\
BMI SDS & 2.7 & $-1.52(-3.73-0.01)$ \\
WFH SDS & 2.34 & $-1.55(-3.78--0.09)$ \\
\hline After 6 months GHT & Patient 2 & Control group 2, $\mathrm{n}=9$ \\
& & median (range) \\
\hline Age, years & 6.5 & $7.3(4.3-10.1)$ \\
Relative weight, \% & 156 & $114.0(100.5-136.8)$ \\
BMI, kg/m ${ }^{2}$ & 23.8 & $17.2(15.1-20.7)$ \\
BMI SDS & 6.6 & $1.30(-0.28-4.18)$ \\
WFH SDS & 7.38 & $1.90(-0.05-4.7)$ \\
\hline
\end{tabular}

months after the institution of GHT. As controls, we chose any child of our study who was between 0 and 1.5 years old and had at that time been treated for 3 months with $\mathrm{GH}$ (table 4). The second child died at the age of 6.5 years, 5 months after the institution of GHT. As controls we used 
any child between 4 and 10 years old who had at that time been treated during 6 months with GH. It turned out that the 2 deceased children of our study were far more obese than all other children of the same age group of our study. The very young patient No. 1 was not only the most obese of his age group, but his weight for height (WfH) SDS increased more than in all other very young patients during the first 3 months of GHT (WfH 0.6 SD at onset of GHT to $2.34 \mathrm{SD}$ some days before he died). The older patient, patient No. 2, was not only the most obese of his age group but also the only in his group who failed to reduce weight and fat mass (WfH SDS 7.3 at onset of GHT and 7.4 after 5 months, 1 month before he died).

\section{Pathophysiological Considerations}

The pathogenesis of the respiratory problems in PWS seems to be multifactorial in origin, including peripheral and central mechanisms. In some patients [1, 2, 14], primary disturbance of respiratory control with abnormally low response to high $\mathrm{pCO}_{2}$ and/or to low $\mathrm{pO}_{2}$ is present already at birth [15]. Sleep apnea is found in $50-100 \%$ of children with PWS leading to alveolar hypoventilation [16]. Irrespective of GHT, children with PWS [1-8] seem to suffer more frequently and from more serious respiratory problems with or without infections than healthy children.

From the data in tables 1 and 2, several pathophysiological explanations may be deduced.

\section{Reduced Diameter of the Upper Airways}

Airway obstruction is caused by pharyngeal muscular hypotonia, facial dysmorphisms (e.g. retrognathia) and/ or tonsillar hyperplasia. Radiological studies of persons with PWS have shown below-average cross-sectional area at the oropharyngeal or nasopharyngeal level [17]. Hyperplastic tonsils in children with PWS and tonsillar infection may further lead to upper airway obstruction. In addition, increased fat depots may also reduce throat diameter.

In fact, we were informed by parents that their children usually sleep with a hyper-extended neck, which can be interpreted as an attempt to optimize the diameter of the throat and of the upper airways, respectively (fig. 1).

\section{Ventilatory Restriction}

The disturbed body composition in PWS, documented from infancy on, might be an important factor for impaired respiration $[18,19]$, especially the decrease in the
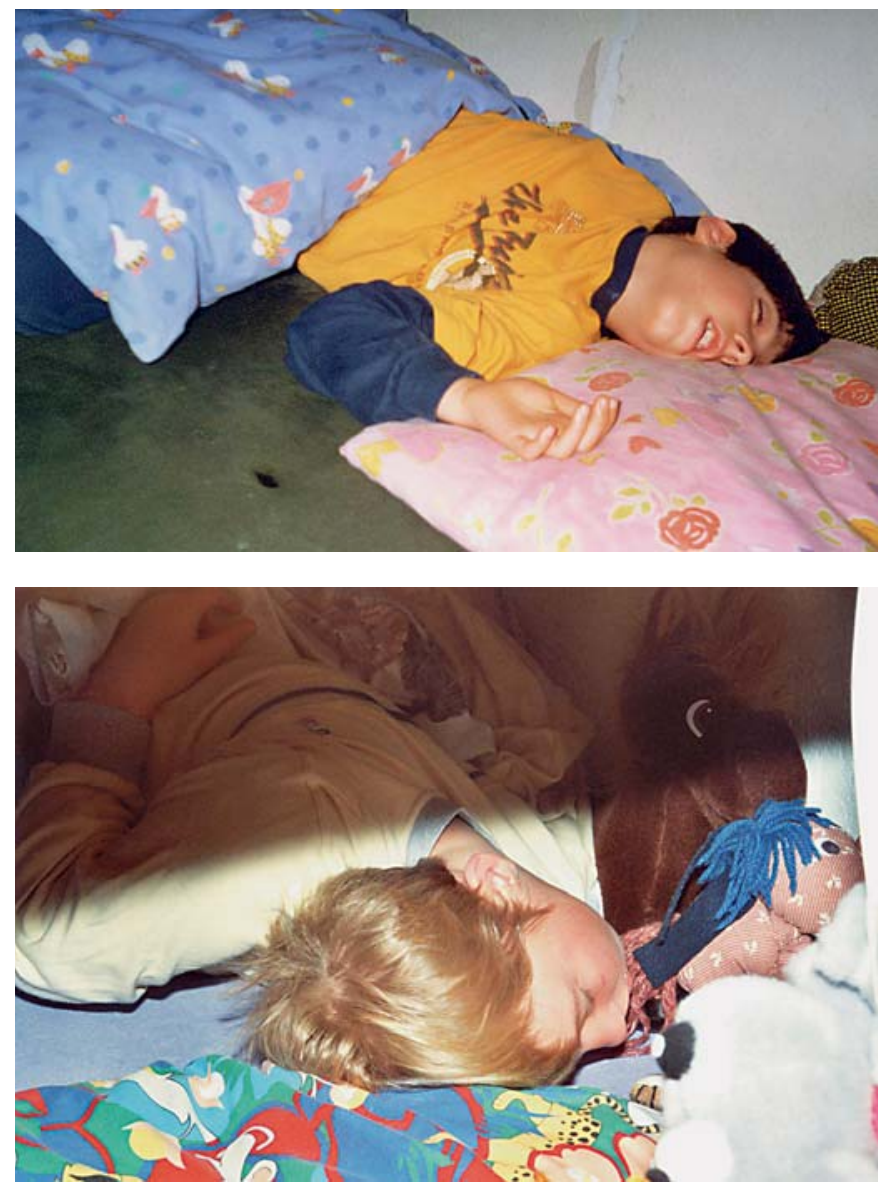

Fig. 1. Neck overextension during sleep in 2 children with PWS indicating the reflex to counteract upper airway obstruction. Informed consent for publication of the photos was obtained from the parents.

mass of the respiratory muscles. The hypothesis that body composition and respiratory muscles are involved in respiratory insufficiency in PWS is supported in studies in children and adults with PWS [16, 20, 21]. The restrictive ventilatory impairment is exacerbated by increased fat depots and possibly aggravated in some cases by kyphoscoliosis.

\section{Disturbances in Respiratory Regulation}

Hypoventilation as a consequence of both mechanisms causes a chronic elevation of $\mathrm{pCO}_{2}$, which further aggravates the situation because of an increase of the respiratory drive set-point in the brain stem. [14, 16, 22].

\section{Respiratory Infections}

Hypoventilation with insufficient air flow also leads to increased infect susceptibility. Thus, about half of the 
children not treated with GH (table 1), as well as at least 7 of 13 of those children who died while on GHT (table 2 ), had shown signs of respiratory tract infection. This further aggravated the existing respiratory insufficiency and thus contributed to their death.

\section{Pulmonary Hypertension}

Alveolar hypoventilation also causes pulmonary vascular obstruction with a pulmonary hypertension and finally cor pulmonale [16]. Signs of a slight pulmonary hypertension were detected in 3 of the children with PWS treated with GH (table 2, patient \#1, by electrocardiography, and by echocardiography in patients \# 2 and \#12, the latter died after a documented increase in pulmonary pressure during GHT [13]).

\section{Possible Impact of GHT on Respiration and Mortality}

As Carrel et al. [22], Lindgren et al. [23] and Haqq et al. [17] showed, the beneficial effects of GHT on growth and body composition are accompanied by an improvement in respiratory function and an increase in $\mathrm{CO}_{2}$ sensitivity. In this context, higher muscle mass and decreased fat mass may improve alveolar ventilation by reducing alveolar $\mathrm{pCO}_{2}$ and thus interrupting the vicious circle through an increased $\mathrm{CO}_{2}$ sensitivity in the brain stem. It is, however, important to note that these studies showed a beneficial effect on respiration as early as after 6 months of therapy.

The following observations underline that GHT influences mortality in children with PWS:

\section{Duration of GHT}

In general, most of the children with PWS were started with GHT 4 years ago, when in 2000, GH was admitted for therapy in PWS, or even earlier in trials with GHT starting in 1992. However, in this context, it is surprising that most children complying with GHT died during the first months on GHT, but not later, except those with preceding heart failure. It may be deduced that GHT increases mortality during the first 7 months of treatment and decreases mortality thereafter, as supported by the data in table 2. In fact, as quoted above, GHT was shown to improve respiratory function after 6 months and, thus, could provide some protection against hypoventilation $[16,21,22]$.

It is nevertheless also conceivable that GHT additionally increases the risk of respiratory insufficiency during the first few months of treatment: First, in those patients with pre-existing distinctively impaired respiration, $\mathrm{GH}$ might augment volume load, because GHT is known to normalize previously decreased hydration during the first few weeks. Second, a tonsillar hyperplasia can be augmented by GHT, and increases the airway obstruction $[24,25]$.

\section{Obesity}

It is striking that most children who died without having received GHT were reported not to have been obese, while those children who died during GHT were more obese than the controls. In addition, our own 2 patients who died differed from our other patients [26], inasmuch as they did not normalize fat mass during GHT. As deduced from longitudinal observation in these 2 patients, the pre-existing and persisting obesity may have further aggravated their respiratory problem. Therefore, data on deceased children with PWS should be analyzed, not only with regard to the level of obesity before the institution of GHT, but also regarding the progression of obesity after the initiation of GHT, since it represents a risk factor for respiratory failure or sudden death. Unfortunately, longitudinal data on other deceased children could not be obtained.

The observation that the children who died spontaneously were younger than the children during GHT, median 2 vs. 4 years, may be due to a recruiting bias. Up to now, only a few children under 2 years of age are being treated with $\mathrm{GH}$ because this age group is only treated in studies in a small number of centers.

\section{Conclusions}

In general, infants with PWS already suffer from hypoventilation. Hypoventilation is probably the consequence of insufficient respiratory muscles, some pharyngeal narrowness and the development of decreased $\mathrm{CO}_{2}$ sensitivity. Obesity plays an important role in fatal outcomes, possibly enhancing the ventilation disorder, as does kyphoscoliosis. Hypoventilation further leads to a higher susceptibility to infections, which in its own right may aggravate respiratory insufficiency. We consider that in most if not all patients who died during GHT, a combination of extreme obesity and pre-existing ventilation disorder might not have been given the attention it merited. We hypothesize that all of these children had hypoventilation with impaired respiratory regulation even before GHT was begun. 


\section{Recommendations}

For several years, we have pointed out the secondary risks of increasing obesity during GHT (www.childgrowth. org). In addition to vigorous weight control by parents and caregivers, we have introduced the following precautionary measures in our outpatient clinic: Before we start with GHT, we perform polysomnography and an otorhinolaryngologic examination and have the patients undergo tonsillectomy if necessary. The parents should find out whether the child snores and should inform us immediately if snoring augments or begins, and also if there are signs of upper airway infections. In this context, in May 2003, Pfizer, the pharmaceutical company which is manufacturing and selling recombinant $\mathrm{GH}$ in the specific indication of PWS, has released a warning on the use of GH in patients with PWS and severe obesity or servere respiratory impairment. They recommended evaluating every child with PWS and GHT as mentioned above.

\section{Acknowledgments}

We are grateful to Dr. Daniel Straub and PD Dr. Hannes Wildhaber, Pneumology Department of the University Children's Clinic in Zurich, for checking the manuscript; Prof. Dr. Max Gassmann, Institute of Veterinary Physiology, Zurich, for discussion of the pathophysiological considerations, as well as PD Dr. Dagmar l'Allemand, Michael Schlumpf and Karin Stutz, Foundation Growth Puberty Adolescence, for their help in editing the manuscript.

\section{References}

-1 Eiholzer U, Nordmann Y,l'Allemand D: Fatal outcome of sleep apnoea in PWS during the initial phase of growth hormone treatment. A case report. Horm Res 2002;58(suppl 3):2426.

-2 Nordmann Y, Eiholzer U, l'Allemand D, Mirjanic S, Markwalder C: Sudden death of an infant with Pader-Willi syndrome: Not a unique case? Biol Neonate 2002;82:139-141.

3 Pharmacia: Pharmacia statement on recently reported cases of death in growth hormonetreated patients with Prader-Willi syndrome, 2003.

-4 Vliet GV, Deal CL, Crock PA, Robitaille Y, Oligny LL: Sudden death in growth hormonetreated children with Prader-Willi syndrome. J Pediatr 2004;144:129-131.

-5 Schrander-Stumpel CT, Curfs LM, Sastrowijoto P, Cassidy SB, Schrander JJ, Fryns JP: Prader-Willi syndrome: Causes of death in an international series of 27 cases. Am J Med Genet 2004:124A:333-338.

-6 Stevenson DA, Anaya TM, Clayton-Smith J, Hall BD, Van Allen MI, Zori RT, Zackai EH, Frank G, Clericuzio CL: Unexpected death and critical illness in Prader-Willi syndrome: Report of ten individuals. Am J Med Genet 2004;124A:158-164.

7 Hayashi M, Itoh M, Kabasawa Y, Hayashi H, Satoh J, Morimatsu Y: A neuropathological study of a case of the Prader-Willi syndrome with an interstitial deletion of the proximal long arm of chromosome 15. Brain Dev 1992; 14:58-62.

-8 Oiglane E, Ounap K, Bartsch O, Rein R, Talvik T: Sudden death of a girl with Prader-Willi syndrome. Genet Couns 2002;13:459-464.

9 Rittinger O: Death in a 3-year-old boy with PWS. Pers commun, 2002.
0 Whittington JE, Holland AJ, Webb T, Butler J, Clarke D, Boer H: Population prevalence and estimated birth incidence and mortality rate for people with Prader-Willi syndrome in one UK Health Region. J Med Genet 2001;38: 792-798.

11 Vogels A, Van Den EJ, Keymolen K, Mortier G, Devriendt K, Legius E, Fryns JP: Minimum prevalence, birth incidence and cause of death for Prader-Willi syndrome in Flanders. Eur J Hum Genet 2004;12:238-240.

12 Bakker B: PWS fatalities from Pharmacovigilance databases and KIGS (Pfizer Global Pharmaceuticals). Pers commun, 2004.

13 Riedl S, Frisch H: Death during growth hormone therapy in a girl with PWS due to an imprinting center mutation. Pers commun, 1999.

14 Schlüter B, Buschatz D, Trowitsch E, Aksu F, Andler W: Respiratory control in children with Prader-Willi syndrome. Eur J Pediatr 1997; 156:65-68.

15 Livingston FR, Arens R, Bailey SL, Keens TG, Ward SL: Hypercapnic arousal responses in Prader-Willi syndrome. Chest 1995; 108: 1627-1631.

16 Haqq AM, Stadler DD, Jackson RH, Rosenfeld RG, Purnell JQ, LaFranchi SH: Effects of growth hormone on pulmonary function, sleep quality, behavior, cognition, growth velocity, body composition, and resting energy expenditure in Prader-Willi syndrome. J Clin Endocrinol Metab 2003;88:2206-2212.

17 Richards A, Quaghebeur G, Clift S, Holland A. Dahlitz M, Parkes D: The upper airway and sleep apnoea in the Prader-Willi syndrome. Clin Otolaryngol 1994;19:193-197.

18 Eiholzer U, Blum WF, Molinari L: Body fat determined by skinfold measurements is elevated despite underweight in infants with Prader-Labhart-Willi syndrome. J Pediatr 1999;134:222-225.
19 Eiholzer U, l'Allemand D, Schlumpf M, Rousson V, Gasser T, Fusch C: Growth hormone and body composition in children younger than 2 years with Prader-Willi syndrome. J Pediatr 2004; 144:753-758.

-20 Hakonarson H, Moskovitz J, Daigle KL, Cassidy SB, Cloutier MM: Pulmonary function abnormalities in Prader-Willi syndrome. J Pediatr 1995; 126:565-570.

21 Carrel A, Myers S, Whitman B, Allen D: Growth hormone improves body composition, fat utilization, physical strength and agility in Prader-Willi syndrome: A controlled study. J Pediatr 1999; 134:215-221.

-22 Lindgren AC, Hellstrom LG, Ritzen EM, Milerad J: Growth hormone treatment increases $\mathrm{CO}(2)$ response, ventilation and central inspiratory drive in children with Prader-Willi syndrome. Eur J Pediatr 1999;158:936-940.

23 Lindgren AC, Ritzen EM: Five years of growth hormone treatment in children with PraderWilli syndrome. Swedish National Growth Hormone Advisory Group. Acta Paediatr Suppl 1999;88:109-111.

24 Gerard JM, Garibaldi L, Myers SE, Aceto T Jr, Kotagal S, Gibbons VP, Stith J, Weber C: Sleep apnea in patients receiving growth hormone. Clin Pediatr (Philad) 1997;36:321-326.

25 Cadieux RJ, Kales A, Santen RJ, Bixler EO, Gordon R: Endoscopic findings in sleep apnea associated with acromegaly. J Clin Endocrinol Metab 1982:55:18-22.

26 Eiholzer U, l'Allemand D, van der Sluis I, Steinert H, Ellis K: Body composition abnormalities in children with Prader-Willi syndrome and long-term effects of growth hormone therapy. Horm Res 2000;53:200-206. 